are most likely to appear around and among active spot-groups, especially groups which are developing and have many component members. At times they follow one another like the balls of a Roman candle, at intervals varying from ten to twenty minutes. Two essential conditions for their observation are good seeing and a large solar image. The appearance suggests something of the nature of an explosion, in which nothing but hydrogen seems to be involved. The level at which the explosions occur would seem to lie below the reversing layer, as the Fraunhofer lines, including those of hydrogen, do not seem to be affected. The phenomenon is quite distinct from the ordinary eruptive reversals of $\mathrm{H} \alpha$, in which the continuity of the dark line is interrupted.

"Annuatre du Bureau des Longitudes."--In addition to the valuable astronomical tables and explanatory matter which ordinarily appear in this well-known official publication, the volume for I9I8 includes a number of articles of special interest. Among these is the first part of an extensive study of sundials by M. Bigourdan; the Egyptian calendar, by the same author; the sun and terrestrial magnetism, by $M$. Hamy; and the life and work of Gaston Darboux, by M. Emile Picard. It should be noted that the tabular matter is not exclusively astronomical, but also includes authoritative data which make the volume a valuable source of reference on questions relating to meteorology, terrestrial magnetism, physics, and chemistry. The Annuaire is published at two francs by Messrs. Gauthier-Villars et Cie.

Third Melbourne Star Catalogue.--The third Melbourne General Catalogue of 3068 stars, for the equinox 1890 , has recently been issued. It is based upon observations made at the Melbourne Observatory during the period 1884 to 1894 , under the direction of Mr. R. J. Ellery, and has been prepared for publication by the present Government Astronomer, Mr. P. Baracchi. The catalogue includes fundamental stars used for the determination of clock-error and azimuth, guide-stars in connection with the astrographic work, and various stars observed for special purposes at the request of other astronomers. The second catalogue, of 12 I I stars, was published in 1889 .

\section{THE ENDOWMENT OF UNIVERSITY AND TECHNICAL EDUCATION.}

M R. H. A. L. FISHER, President of the Board of Education, speaking at Birmingham on January $3 \mathrm{I}$, referred to the support afforded to higher education in the United States and Germany in comparison with that in England. He is reported by the Times to have said that "he had been looking into the endowments from private sources which have been going to the American universities on one hand, and to the English universities on the other, in recent years. In the period from 1906 to 1917 the American universities received an average of more than four millions annually from private sources, whereas our universities were lucky if they received $200,000 l$. in one year. Concerning the amount of State help to the universities in Prussia on one hand, and in England and Wales on the other, whereas the Prussian universities receive rather more than a million pounds a year, our universities and technical institutes receive 378 ,oool. from the rates and taxes combined. The comparison is even more unfair to England than it appears at first sight, because the Prussian figures exclude the endowments of the technical institutions and sums paid by the State to assist the training of teachers."

We are glad that Mr. Fisher has directed attention to the need for more liberal provision for university and higher technical education in this country, as indicated by the support offered in other countries. The most complete survey of State-aid and private endowments for scientific and educational purposes is that given annually in the report of the British Science Guild; and in connection with Mr. Fisher's remarks it is of interest to extract the following facts from such reports published in recent years :-

(I) The grand total of gifts to education in the United States during the forty-four years I87IIgI4 was $x 16,883,600 l$. The average annual amount of new benefactions during the four years I9II-I4 was six million pounds, excluding grants by the United States, different States, and municipalities; in the United Kingdom, the average is less than one-twentieth this amount.

(2) The total receipts of universities in the United States in the year I9IO-II amounted to nearly nineteen million pounds, and the benefactions to five millions. In the same financial year, the total incomes of those universities and university colleges in Great Britain which are in receipt of $\mathrm{S}$ iate grants was little more than one-seventh of the amount of gifts to education in the States, and was less than onethirtieth of the incomes of the universities there.

(3) The income from endowments in the case of the universities and university colleges receiving Treasury grants is about $85,000 l$. for England and $4000 l$. for Wales; or, say, 90, oool. for Great Britain. Five universities in the United States have each a much greater income from private endowment funds alone than the total endowment income of State-aided universities and university colleges in Great Britain. They are :Harvard University, 239,50ol.; Columbia University, 199,700l. ; Leland Stanford Junior University, 177,40ol.; University of Chicago, I64,700l.; and Yale University, I40,900l.

(4) Our Treasury grants in aid of experses of universities and university colleges amount to about 300,000 . The Treasury grants of the United States Government to universities and colleges amount to $\mathrm{I}, \mathrm{I} 75,000 \mathrm{l}$., and the State or city grants for current expenses to $2,940,000 l$. or more than $4,000,000 l$. in all. The contributions of several single States in the United States, from State or city funds, for current expenses of universities and other institutions of higher education approach the total amount of the grant made for like purposes in Great Britain.

(5) In Germany, State subsidies provide the main part of the incomes of the universities. The annual expenditure for the universities from State funds amounts in round figures to $1,800,000 l$. In Igr 3 the expenditure of the University of Berlin alone was $24^{2}, 000 l$.; and of this amount $200,000 l$., or about 83 per cent., was derived from State funds.

(6) The total number of full-time day students in the universities of the United Kingdom is about $2 \mathrm{I}, 000$, in comparison with 55,000 in German universities. In our technical institutions, the number of day students in attendance is about 2000 , in comparison with 16,000 in the technical high schools of Germany. The seventytwo universities, colleges, and technical schools in the United States, on the accepted list of the Carnegie Foundation for the Advancement of Teaching, had, in I910, 89,000 students.

It is evident that we have much leeway to make up in order to increase the number of highly trained men required to enable us to come into line with the United States and Germany as regards the provision for the scientific development of our industries. There is no more important problem of reconstruction than that of extending our facilities for higher education, yet almost nothing has been done to enable our universities and technical institutions to provide for the extensions which are needed for national security in the future. 
As we have now a really democratic President of the Board of Education, who has a genuine zeal for education and a fervent desire that all who are capable of benefiting from it shall have the means of enjoying its advantages, we may hope that steps will be taken to place our universities and technical institutions upon a satisfactory financial footing. In an address delivered in September last to the Associated Educational Societies of Manchester, on "Educational Reform," recently issued in pamphlet form, Mr. Fisher surveyed the whole field of education, and directed attention to the great increase in the number of universities now existing in England and Wales, comprising twelve, including the ancient universities of Oxford and Cambridge. Mr. Fisher characterised these as in the forefront of European learning, and said they need not fear comparison with the most famous universities of the Continent in respect either of the quality of their contributions to the advance of knowledge or of the adequacy and power of their teaching. The ten more modern universities, which are largely subsidised by the State, have not yet received an equipment at all adequate to modern needs, and are nowhere supported by so large a body of students as they deserve. Attention was directed to a comparison between Lancashire and Scotland, with a similar population. In the former there are two universities, in the latter five, with, in the case of Scotland, a body of undergraduates five times as numerous as that of the Universities of Manchester and Liverpool combined.

The place and function of the secondary school in its relation to the university were also discussed by $\mathrm{Mr}$. Fisher. While the number of such schools has greatly increased, there being nearly 1000 in receipt of education grants, there is in many areas very inadequate provision, to the great detriment of the children residing therein. There are too many early leavers and too low a percentage of pupils who reach matriculation standard. Much needs to be done before the secondary schools can reach a proper level. Better salaries must be offered to the teachers and an adequate scale of pensions arranged. More encouragement must be offered to induce a higher standard of work, and so enable the universities to reach a higher plane of teaching. More and better provision is needed in the way of maintenance scholarships enabling capable, though poor, children to travel along the broad highway unimpeded from the elementary school to the university. Whilst the work of the elementary school has much improved of late it can never do its full worls until the leaving age is made compulsory up to fourteen at least, and provision then made for a liberal, continued education within working hours for those entering industry up to eighteen years of age.

One point which has been overlooked in recent discussions is that of the need for improvement of the scales of salaries of teachers in universities and technical institutions if competent instructors are to be maintained. A meeting of teachers engaged in the technical institutes, junior technical and trades schools of London and the neighbouring counties was held on Saturday last to consider this question. Special emphasis was laid by several speakers on the fact that men and women of attainments similar to those of teachers in technical institutions can obtain much higher salaries in industry or in secondary schools than are paid in the technical institutions. A resolution declaring that the present rates of salaries paid to both day and evening teachers in technical institutions are totally inadequate, and urging the education authorities to take immediate steps to establish satisfactory scales of salaries for all teachers, was carried unanimously. A further resolution requesting the Government to allocate special grants, similar to those given in the case of secondary and elementary schools, for improving the salaries of teachers in technical institutions was also adopted. It was agreed that the London Branch of the Association of Teachers in Technical Institutions, by whom the meeting was organised, should request the County Councils of London and the Home Counties to receive deputations for the purpose of placing the views of the meeting before them.

\section{MAGNETIC SURVEY OF NEW ZEALAND.}

$\mathrm{N}$ the observational work recorded in the publication referred to below Dr. Farr had much assist. ance from Mr. Skey, who succeeded him as director of the Christchurch Magnetic Observatory when Dr. Farr became professor of physics at Canterbury College, while Mr. D. B. MacLeod took an active part in the discussion of results. The observational work extended over the years 1899 to 1909 , in the course of which 334 stations were occupied, including forty-four in the Southern Islands, Chathams, and West Coast Sounds. The instruments, a unifilar magnetometer and dip circle-the former once used by the North American Boundary Commission, and by the Jackson-Harmsworth Polar Expedition-were lent by the old Kew Committee of the Royal Society.

Particulars are given of the position of each station, the date or dates of observation, the values of the declination, dip, east and north components, horizontal, vertical, and total forces. Owing to the long period covered by the observations, considerable importance attaches to the secular change corrections necessary to reduce the data to a common epoch. These were based on the magnetograph data obtained at Christchurch from Igor onwards, and on observations at repeat stations. Following the example afforded by Rücker and Thorpe's survey of the British Isles, New Zealand was divided into ten overlapping districts. These were bounded by parallels of latitude, the limits of three successive ones being, for instance, $38^{\circ}$ and $40^{\circ} \mathrm{S}, 3^{\circ}$ and $41^{\circ} \mathrm{S}$., and $40^{\circ}$ and $42^{\circ} \mathrm{S}$. Assuming the change in any element within any one district a linear function of the latitude and longitude, the rates of change with latitude and longitude were deduced in the first instance by the method of least squares. A process of smoothing was then applied, to secure continuity in passing from one district to the next.

The general nature of the results is best seen by consulting the maps. The great length of New Zealand from north to south necessitates two maps for each element, one for the North Island, the other for the South Island. The latter, it should be noticed, is described as the "Middle Island" in the charts principally devoted to the North Island, a memory of the time when the small island, now known as Stewart Island, was called the South Island. In the case of the declination, starting at the extreme north of the North Island, we have the isogonal of $14^{\circ} \mathrm{o}^{\prime} \mathrm{E}$., slop. ing from N.W. to S.E. Near the south of the North Island, and north of the South Island, the isogonal of $15^{\circ} 50^{\prime}$ runs nearly due east and west, while to the extreme south of the South Island the isogonal of $17^{\circ} 10^{\prime}$ slopes from N.E. to S.W. The isoclinals and lines of equal horizontal force, on the other hand, have a nearly parallel trend from extreme north to south. The dip ranges from under $60^{\circ} \mathrm{S}$. to over $7 \mathrm{I}^{\circ}$ S., and the horizontal force from 0.275 C.G.S. in the extreme north to o.20o C.G.S. in Stewart Island.

Other maps deal with the northerly, east, and vertical components, and the total force. The two last

1 "A Magnetic Survey of the Dominion of New Zealand and Some of the Outlying Islands for the Epoch June 30, 1903." By Dr. C. Coleridge Farr. Pp. $64+2$, with 18 maps. (Wellington : John Mackay, Government Printer,
1916.) NO. 25 I9, VOL. IOO] 